\title{
PENYELESAIAN SENGKETA TANAH SOKO PADA SUKU BENDANG KAMPAR RIAU DENGAN CORAK HUKUM ISLAM
}

\author{
Hengki Firmanda ${ }^{1}$ \\ ${ }^{1}$ Universitas Riau, Riau \\ *CORRESPONDENCE: $\square$ hengki.firmanda@gmail.com
}

\begin{abstract}
The purpose of this study was to describe the ownership status of Soko land in Article History indigenous peoples will not be separated from their customary lands. The existence of indigenous peoples will be determined by ownership of their customary land. Indigenous people will not be called indigenous peoples without owning their customary land. This type of research is sociological legal research, namely research in the form of empirical studies to find theories about the process of occurrence and the process of working the law in society. The results of this study are, the status of ownership of Soko land in the indigenous people of the kampar tribe of the kampar district is attached to the community that has a maternal lineage. The transfer of ownership of soko land to the indigenous people of the dam tribe of Kampar District is the transfer of ownership of land between generations according to lineage and the transfer of land ownership to the settlement of land disputes.
\end{abstract}

Article Info

the Indigenous People of the Bendang Tribe, Kampar, Riau; and explain the Received:25-11-2018, settlement of the transfer dispute over the ownership of Soko Land to the Revised :27-12-2018,

Indigenous People of the Bendang Tribe, Kampar, Riau. The existence of Accepted:28-12-2018

\section{Keywords: \\ Land Ownership \\ Transition; \\ Soko Land ; \\ Bendang Tribe ;}

\begin{abstract}
Abstrak
Tujuan penelitian ini adalah untuk menguraikan tentang status kepemilikan tanah Soko pada Masyarakat Adat Suku Bendang, Kampar, Riau; dan menjelaskan tentang penyelesaian sengketa peralihan kepemilikan Tanah Soko pada Masyarakat Adat Suku Bendang, Kampar, Riau. Eksistensi masyarakat adat tidak akan terlepas dari tanah adatnya. Keberadaan masyarakat adat akan ditentukan oleh kepemilikan tanah adatnya. Masyarakat adat tidak akan disebut sebagai masyarakat adat tanpa memiliki tanah adatnya. Jenis penelitian ini adalah penelitian hukum sosiologis, yaitu penelitian berupa studi empiris untuk menemukan teori-teori mengenai proses terjadinya dan mengenai proses bekerjanya hukum dalam masyarakat. Adapun hasil dari penelitian ini adalah, (1) Status kepemilikan tanah soko pada masyarakat adat suku bendang kabupaten kampar dilekatkan pada komunitas masyarakat yang memiliki garis keturunan ibu. (2) Peralihan kepemilikan tanah Soko pada masyarakat adat suku Bendang Kabupaten Kampar adalah peralihan kepemilikan tanah antar generasi Tanah Soko; menurut garis keturunan dan peralihan kepemilikan tanah atas penyelesaian Suku Bendang; sengketa tanah.
\end{abstract}

\section{A. Pendahuluan}

Hukum tanah di Indonesia dari zaman penjajahan hingga saat ini bersifat dualisme, yang dapat diartikan bahwa status hukum atas tanah ada yang dikuasai oleh hukum Eropa, dan ada yang dikuasai oleh hukum adat[1]. Dualisme hukum ini terjadi karena Indonesia pernah dijajah oleh Belanda, sehingga hukum Belanda menjadi salah satu pemenuhan hukum di Indonesia. Jauh sebelum Belanda menjajah Indonesia, hukum yang digunakan pada saat itu adalah hukum yang 
hidup di tengah-tengah masyarakat yaitu hukum adat. Hukum tentang tanah juga mendapatkan pengaruh dari dualisme hukum tersebut.

Hukum adat tentang tanah menyangkut hubungan masyarakat adat dengan tanah, sehingga hukum adat itu linier dengan masyarakatnya dan masyarakatnya linier dengan hukumnya. Hubungan antara masyarakat adat dengan tanahnya merupakan pembahasan yang telah ada sejak dahulu di tingkat internasional, di negara manapun masyarakat menganggap bahwa hubungannya dengan tanah tidak hanya selalu mengenai masalah ekonomi, tetapi juga hubungan secara sosial dan spiritual. Kuatnya sistem penguasaan tanah menurut hukum adat merupakan cerminan budaya dan ekonomi yang hidup dan berlangsung secara terus menerus. Ada ikatan antara masyarakat adat dengan tanah yang tidak bisa dilepaskan satu dengan yang lainnya. Ikatan tersebut menciptakan interaksi, dan interaksi yang muncul antara masyarakat adat dengan tanah bukan hanya menyangkut interaksi antara subjek dan objek, melainkan ada dimensi ikatan kebatinan, bahkan sampai kepada ikatan religius magisnya[1].

Eksistensi masyarakat adat tidak akan terlepas dari tanah adatnya. Keberadaan masyarakat adat akan ditentukan oleh kepemilikan tanah adatnya. Masyarakat adat tidak akan disebut sebagai masyarakat adat, tanpa memiliki tanah adatnya. Begitulah hubungan yang kuat antara masyarakat adat dengan tanah adat, yang saling mempengaruhi satu dengan yang lainnya. Eksistensi masyarakat adat juga diakui oleh konstitusi yang dijabarkan di dalam Pasal 18B Ayat (2), yang mana negara mengakui dan mengormati kesatuan-kesatuan masyarakat hukum adat serta hak-hak tradisionalnya. Hal ini menunjukkan bahwa hukum adat itu merupakan hukum yang benar-benar hidup dalam kesadaran hati nurani masyarakatnya.

Hubungan antara masyarakat adat dengan tanah adat menimbulkan hak dan kewajiban. Berdasakan hukum adat di Indonesia yang menyangkut tentang tanah menimbulkan 2 (dua) macam hak, yaitu: (a) Hak persekutuan, adalah hak atas tanah yang dimiliki, dikuasai, dimanfaatkan, dan dinikmati oleh masyarakat hukum adat pada suatu wilayah. Hak ini sering disebut hak ulayat, (b) Hak perseorangan, ialah hak atas tanah yang dimiliki, dikuasai, dimanfaatkan, dan dinikmati oleh individu orang.

Ter Haar menyebutkan tentang hubungan antara hak persekutuan dan hak perorangan ialah dapat dilihat dengan jelas bahwa umat manusia itu ada yang berdiam di suatu pusat tempat kediaman yang selanjutnya disebut masyarakat desa atau mereka ada yang berdiam secara tersebar di pusat-pusat kediaman yang sama nilainya satu sama lain, di suatu wilayah yang terbatas, maka dalam hal ini merupakan suatu masyarakat wilayah.

Tiap masyarakat adat dapat memenuhi keperluan hidupnya, karena memiliki hutan, tanah dan wilayah perairan dengan segala keakayaannya. Wilayah yang didiami oleh suatu masyarakat adat lazim disebut tanah ulayat. Tanah ulayat adalah suatu wilayah yang dimiliki, dipelihara bersama oleh masyarakat adat untuk memberikan sebanyak mungkin kesejahteraan kepada warganya. Tanah ulayat itu dapat meliputi Tanah pekarangan; Tanah peladangan; Tanah kebun; Rimba kepungan sialang; Rimba simpanan (larangan); Perairan penangkapan ikan; Padang pengembalaan; Tanah kandang; Tanah koto; dan Tanah perkuburan.

Tanah di Kampar saat ini seluas 1.128.928 Ha yang terbagi menjadi: (a) lahan perkebunan digunakan seluas 353.505 Ha (32.19 persen) yang meliputi sawit, karet, kelapa, gambir dan lainlain, (b) luas panen padi sawah sebesar $10.088 \mathrm{Ha}$, dan luas panen padi ladang sebesar 5.228 Ha, (c) luas panen Palawija terdapat jagung seluas 1.641 Ha, ubi kayu $850 \mathrm{Ha}$, Ubi jalar $245 \mathrm{Ha}$, kacang tanah $540 \mathrm{Ha}$, kedelai $369 \mathrm{Ha}$, dan kacang hijau $232 \mathrm{Ha}$, (d) luas Hutan sebesar 497.029,77 Ha, 
yang dibagi menjadi hutan lindung sebanyak 6.07 persen, hutan konservasi sebanyak 11.09 persen, hutan produksi terbatas sebesar 63.96 persen, dan hutan produksi tetap sebanyak 8.65 persen.

Luas tanah menurut penggunaan Tahun 2014 yang diterbitkan oleh Dinas Pertanian Kabupaten Kampar dalam Kampar dalam Angka 2015 membagi menjadi tanah sawah seluas 8.934 Ha; Pekarangan, Bangunan dan lahan sekitarnya seluas $383.344 \mathrm{Ha}$; Tegal Kebun seluas 92.673 Ha; Ladang Huma seluas 52.988 Ha; Padang Rumput seluas 9.920 Ha; Rawa tidak ditanami seluas 19.275 Ha; Kolam seluas 6.113 Ha; Sementara tidak diusahakan seluas 34.575 Ha; Hutan Negara dan Hutan Rakyat seluas 67.506 Ha; Perkebunan seluas $403.450 \mathrm{Ha}$; dan lain-lain seluas 50.150 Ha.

Data yang ditampilkan oleh Badan Pusat Statistik menyebutkan bahwa kasus terkait dengan tanah yang dilaporkan dan yang diselesaikan oleh Polres Kampar ialah yang dilaporkan sebanyak 12 (Dua Belas) kasus, dan yang diselesaikan sebanyak 5 (lima) kasus. Pelaporan tersebut terkait dengan kasus penyerobotan tanah (land appropriate) yang dilaporkan. Pada prinsipnya ada banyak kasus yang menyangkut tanah di kabupaten Kampar yang tidak dilaporkan karena rumitnya penyelesaian hukum melalui hukum formal. Ada juga beberapa kasus terkait terbakarnya hutan yang berada dalam area tanah ulayat masyarakat hukum adat.

Ramli Bey menyebutkan pada masyarakat adat Kampar membagi tanah menjadi 3 (tiga) yaitu: (a) Tanah sako atau tanah soko yang turun temurun, (b) Tanah Pusako yaitu tanah pembelian orang tua, (c) Tanah Wilayat Nenek Mamak Negeri Limo Koto Rimba/hutan cukup luas yang menghasilkan Karet, Rotan, Jelutung, Damar, Manis Lebah dan Pinang serta bermacam-macam hasil jenis kayu yang bermutu baik.

Tanah Soko merupakan tanah yang diberikan melalui garis keturunan ibu/perempuan yang diberikan secara turun temurun. Tanah ini disebut juga tanah sepersukuan yang diberikan berdasarkan garis suku ibu dan ke anak perempuannya, serta begitu selanjutnya. Tanah soko dapat dikatakan bahwa tanah yang dimiliki oleh garis keturunan ibu yang satu suku. Ramli Bey menjelaskan bahwa di Kampar terdapat beberapa suku yaitu di antaranya adalah Suku Domo, Suku Pitopang, Suku Piliang, Suku Mandailiang, Suku Kampai, Suku Melayu dan Suku Bendang. Kesemua suku tersebut memiliki tanah sokonya masing-masing berdasarkan sukunya masingmasing.

Permasalahan tanah soko pernah terjadi pada masing-masing suku di Kampar, begitu juga pada masyarakat adat Suku Bendang. Permasalahan tersebut tidaklah diselesaikan menurut hukum nasional yang ada di Indonesia, melainkan masyarakat adat lebih mempercayai cara-cara penyelesaian hukum adat. Oleh karena itu menarik untuk membahas tinjauan hukum tentang peralihan hak kepemilikan tanah soko pada suku Bendang di Kabupaten Kampar. Hal tersebut dikarenakan bahwa kepemilikan tanah soko dapat beralih ke keluarga yang berbeda namun tetap di dalam suku yang sama. Perselisihan sesama suku akan sering terjadi apabila tidak dibijaki dengan baik, apalagi hal itu menyangkut tentang tanah, karena tanah merupakan hal yang sangat penting bagi masyarakat adat.

Pada prinsipnya Kabupaten Kampar di Riau dikenal sebagai serambi Makkahnya Provinsi Riau. Tumpuan cara-cara berhukumnya adalah selalu berupaya diselesaikan dengan cara-cara Islam yang dikolaborasikan dengan hukum adat, walaupun pada prinsipnya tetap mengacu kepada adat bersandi syara', dan syara' bersandi kitabullah. Walaupun penerapannya tidak sama persis dengan praktek-praktek ke-Islaman pada umumnya, tetapi nilai-nilai ke-Islaman dijunjung tinggi. Hukum yang paling tinggi tetap mengacu pada Alquran dan Sunnah, baru kemudian hukum adat tempatan. Dengan demikian, pertanyaan penelitian yang diajukan peneliti adalah bagaimana status 
kepemilikan Tanah Soko pada Masyarakat Adat Suku Bendang Kabupaten Kampar, pertanyaanselanjunya adalah bagaimana peralihan hak kepemilikan dan penyelesaian sengketa Tanah Soko pada Masyarakat Adat Suku Bendang Kabupaten Kampar.

Kajian tentang penyelesaian sengketa tanah Soko pada suku di Kampar belum dilakukan oleh peneliti lain. Peneliti menemukan kajian dengan objek yang sama dengan pendekatan yang berbeda. Penelitian tersebut berjudul "Kerukunan dan Kearifan Lokal dalam Hak-Hak Masyarakat Hukum Adat Kampar" yang ditulis oleh Erman dan Afdhal Renaldi[2]. Dalam penelitian tersebut keduanya menyimpulkan bahwa dalam menjaga kerukunan dan kearifan lokal, maka permasalahan tanah merupakan hal yang esensial diperhatikan. Mengingat bahwa menurut suku Kampar, tanah merupakan gambaran superioritas keluarga. Salah satu jenis tanah yang dimiliki oleh suku Kampar adalah tanah ulayat sebagai tanah otonom. Tanah tersebut merupakan simbol dari kultur Kampar, simbol kedudukan sosial, dan pertumbuhan ekonomi. Selain itu ada juga tanah yang dinamakan dengan tanah pusaka atau pusako. Tanah pusako merupakan tanah warisan yang turun-temurun dari ibu. Ada juga tanah anggun-anggun yang merupakan tanah lapang yang berada di tengah daerah yang dikuasai kepala suku. Dalam penelitian ini, peneliti lebih fokus mengkaji tentang tatacara penyelesaian sengketa tanah, khususnya tanah yang bersifat tanah pusaka, pusako atau soko. Dengan demikian peneliti melakukan kajian terhadap penyelesaian sengketa tanah melalui prespektif Hukum Islam yang belum pernah dilakukan oleh peneliti-peneliti sebelumnya.

\section{B. Metode Penelitian}

Jenis penelitian ini adalah penelitian hukum sosiologis, yaitu penelitian berupa studi empiris yang untuk menemukan teori-teori mengenai proses terjadinya dan mengenai proses bekerjanya hukum dalam masyarakat[1] Studi empiris merupakan studi yang menemukan fakta sesuai dengan yang terjadi seperti apa adanya fakta tersebut.

Lokasi penelitian adalah di Kabupaten Kampar yaitu Lembaga Adat Kampar (LAK), datuk dan mamak pada masyarakat adat Suku Bendang. Sampel adalah sebagian dari populasi yang dapat mewakili keseluruhan objek penelitian yang mempermudah peneliti dalam menemukan data-data yang dibutuhkan untuk menjawab permasalahan pada penelitian[4]. Cara penentuan ukuran sampel adalah dengan cara Purposive Sampling yaitu pengambilan sampel yang disesuaikan dengan tujuan penelitian, ukuran sampel tidak dipersoalkan, sampel yang diambil hanya yang sesuai dengan tujuan penelitian. Pada penelitian ini yang menjadi sampelnya adalah: (a) Ketua Lembaga Adat Melayu Riau (LAM Riau), (b) Ketua Lembaga Adat Kampar (LAK), (c) Datuk yang dituakan pada masyarakat adat Suku Bendang Kabupaten Kampar, dan (d) Ninik Mamak pada masyarakat adat Suku Bendang Kabupaten Kampar.

Sumber data yang diperoleh dari penelitian ini terbagi menjadi 2 (dua) yaitu sumber data primer dan sumber data sekunder. Sumber data primer ialah sumber data yang diperoleh langsung dari lapangan. Peneliti langsung turun ke lapangan untuk mencari data-data. Peneliti memperoleh data primer melalui wawancara langsung dengan orang yang berkopeten untuk menjawab pertanyaan-pertanyaan peneliti.

Sumber data sekunder adalah sumber data yang diperoleh dari data-data kepustakaan, guna untuk mendukung data primer. Data sekunder terbagi menjadi 3 (tiga) jenis yaitu Bahan Hukum Primer, Bahan Hukum Sekunder, dan Bahan Hukum Tersier. Bahan Hukum Primer yaitu berupa hukum adat kampar dan buku-buku utama yang menjadi referensi utama. Bahan Hukum Sekunder ialah bahan kepustakaan yang berupa buku-buku pendukung beserta referensi lainnya yang sesuai 
dengan yang diteliti oleh peneliti. Bahan Hukum Tersier adalah bahan kepustakaan yang membantu menafsirkan bahan-bahan hukum primer dan tersier seperti ensiklopedia dan kamus yang sesuai dengan kebutuhan penelitian.

Teknik pengumpulan data yang peneliti gunakan ialah terbagi menjadi 2 (dua), yaitu Data Primer dengan menggunakan observasi serta wawancara, dan Data Sekunder dengan menggunakan Data Kepustakaan. Data primer yaitu data yang dikumpulkan melalui data lapangan. Data sekunder yaitu data-data yang diambil melalui data kepustakaan. Teknik Pengumpulan Data melalui data kepustakaan yang peneliti lakukan ialah dengan menggunakan teknik menemukan referensireferensi utama dan pendukung.

Analisis data yang digunakan dalam penelitian adalah analisis kualitatif yaitu uraian yang dilakukan terhadap data yang terkumpul dengan tidak menggunakan angka-angka tetapi berdasarkan peraturan perundang-undangan dan pendapat pakar hukum, selanjutnya peneliti menerangkan dengan jelas dan rinci melalui interprestasi data dengan menghubungkan keterkaitan data yang satu dengan yang lainnya dan dianalisa berdasarkan teori hukum maupun ketentuan hukum yang berlaku dan pendapat para ahli, untuk kemudian menarik kesimpulan dengan cara induktif yakni penarikan kesimpulan dari hal-hal yang bersifat khusus kepada hal-hal yang bersifat umum.

\section{Pembahasan atau Analisis}

\section{Status Kepemilikan Tanah Soko pada Masyarakat Adat Suku Bendang Kabupaten Kampar}

Tanah adalah harta yang bernilai tinggi bagi masyarakat hukum adat, karena dari hasil wawancara dengan Ketua LAK (Lembaga Adat Kampar) yaitu Dt. H. Ramli. R, pada hari Selasa, tanggal 25 Oktober 2016, pukul 09.10 Wib, di Kantor LAK (Lembaga Adat Kampar) Kab.Kampar, mengatakan bahwa tanah merupakan sumber hidup dan kehidupan manusia. Dikatakan sumber hidup adalah tanah sebagai tempat tinggal manusia dan selalu memberikan hasil-hasilnya kepada manusia. Dikatakan tanah sebagai kehidupan manusia karena tanah adalah tempat seluruh kegiatan manusia mencari kehidupannya seperti bersawah, beternak, berladang, tempat kolam ikan, dan lain sebagainya.

Hubungan manusia dengan tanah pada dasarnya dapat dilihat dalam 2 (dua) hubungan, yaitu: (a) Manusia sebagai pengguna alam (tanah) (human as land users atau use-oriented law), yaitu manusia berharap kepada tanah, bergantung kepada hasil-hasil tanah, dan manusia sebagai subjek yang dikendalikan oleh alam karena ketergantungannya. Manusia tidak berbuat banyak dalam pengelolaannya, melainkan hanya bergantung kepada alam. Ini menjadikan manusia sebagai subjek yang terpengaruhi atau dipengaruhi. Cara pandang ini digunakan oleh sebagian masyarakat hukum adat, terutama masyarakat hukum adat yang sikap hidupnya adalah nomaden (berpindahpindah), (b) Manusia sebagai mitra alam (tanah), cara pandang yang memposisikan manusia dan alam (tanah) merupakan saling mempengaruhi. Eksistensi keduanya saling melengkapi satu dengan yang lainnya, sehingga ada hubungan relasional struktural antara keduanya. Manusia dan tanah sama-sama membentuk dirinya dalam satu kesatuan yang harmonis. Ketika manusia mengelola tanah, maka manusia harus memahami posisi tanah bukan hanya untuk kebutuhan manusia saja, melainkan ada situasi yang memperhatikan tanah. Manusia bukanlah subjek tunggal yang mempengaruhi, tetapi memposisikan setara bahwa alam atau tanah juga sebagai subjek. 
Tanah adat atau tanah suku atau tanah ulayat merupakan hak ulayat yang menunjukkan adanya hubungan hukum antara masyarakat hukum adat dengan tanah wilayahnya. Tanah ini dikuasai oleh persekutuan masyarakat hukum adat yang didasarkan atas kesamaan keturunan (genealogis) dan/atau kesamaan tempat tinggal (teritorial)[5] Ikatan antara manusia dan tanah erat kaitannya dengan nilai religius magis dan begitu terus menerus secara turun temurun mulai dari masa penguasaan tanah oleh para leluhur. Kebiasaan secara turun temurun dilaksanakan dengan persetujuan ninik mamak, datuk, serta penghulu negeri[6]

Sebelum melihat status kepemilikan tanah soko, secara umum yang dikatakan oleh Ketua LAK (Lembaga Adat Kampar) yaitu Dt. H. Ramli. R adalah ada 2 (dua) jenis kepemilikan tanah pada masyarakat hukum adat Kampar yaitu: (a) Tanah Hak Pusako, adalah tanah hak milik, artinya tanah yang diperoleh secara individu baik dengan cara jual beli atau pun dengan cara lainnya. Tanah pusako juga dimaknai dengan tanah pemberian dari orang tua sendiri, (b) Tanah Hak Soko, (tanah soko) merupakan tanah turun temurun yang asalnya bisa dari tanah ulayat dan bisa dari tanah turun temurun yang berasal dari nenek moyang dahulu.

Ramli Bey mengatakan ada 3 (tiga) jenis kepemilikan tanah pada masyarakat adat Kampar, di antaranya adalah (a) Tanah sako atau tanah soko yang turun temurun; (b) Tanah Pusako yaitu tanah pembelian orang tua, dan; (c) Tanah Wilayat Nenek Mamak Negeri Limo Koto Rimba/hutan cukup luas yang menghasilkan Karet, Rotan, Jelutung, Damar, Manis Lebah dan Pinang serta bermacam-macam hasil jenis kayu yang bermutu baik[7].

Jenis kepemilikan tanah pada masyarakat hukum adat Kampar juga dijelaskan dalam Peraturan Daerah Kabupaten Kampar Nomor 12 Tahun 1999 tentang Hak Tanah Ulayat, yaitu pemerintah daerah secara hukum mengakui jenis kepemilikan tanah komunal berupa Hak Tanah Ulayat. Lahirnya perda ini diawali oleh Undang-Undang Nomor 5 Tahun 1960 tentang PokokPokok Agraria dan Peraturan Menteri Agraria atau Kepala Badan Pertanahan Nasional Nomor 5 Tahun 1999 yang menjadi kebijakan awal yang mengatur pengakuan hak masyarakat adat atas tanah[8]. Pasal 1 Huruf (h) Perda Kampar No. 12 Tahun 1999 menyebutkan Hak Tanah Ulayat adalah merupakan salah satu harta milik bersama suatu masyarakat hukum adat, yang mencakup suatu kesatuan wilayah berupa lahan pertanahan, tumbuhan yang hidup secara liar dan binatang yang hidup liar di atasnya. Hak tanah ulayat ini memiliki fungsi untuk meningkatkan kesejahteraan anggota persekutuan dan masyarakat yang bersifat sosial dan ekonomis.

Al Azhar selaku Ketua Lembaga Adat Melayu Riau juga menjelaskan tentang pembagian tanah bahwa tanah ulayat di dalam Adat Melayu Riau secara keseluruhannya terbagi menjadi: (a) Tanah kayat atau tersurat, ialah tanah yang dikuasai sultan dan raja, (b) Tanah ulayat, yaitu tanah yang ditempati oleh suku-suku setempat, yang penguasaannya diberikan kepada ninik mamak dan datuk-datuk, (c) Tanah hayat atau tumbuh yaitu tanah yang sebelumnya tidak ada, dan belakangan menjadi ada seperti delta atau tanah tumpukan yang membentuk sebuah pulau, contohnya Pulau Godang Kampar.

Jenis kepemilikan tanah pada masyarakat hukum adat Kampar jika dilihat dari pendapat Dt. H. Ramli. R (Ketua Lembaga Adat Kampar), Ramli Bey, Al Azhar dan Peraturan Daerah Kabupaten Kampar Nomor 12 Tahun 1999, maka jenis kepemilikan tanah pada masyarakat hukum adat Kampar pada khususnya dan Riau pada umumnya dapat disimpulkan dan dibagi menjadi: (a) Tanah Kayat yang dimiliki sultan atau raja, (b) Tanah pusako yang dimiliki oleh individu, (c) Tanah Soko yang dimiliki oleh kelompok suku tertentu, (d) Tanah Wilayat yang dimiliki oleh komunal namun telah dimanfaatkan atau dikelola, (e) Tanah Ulayat yang dimiliki oleh masyarakat hukum 
adat secara komunal, (f) Tanah hayat atau tanah tumbuh, yang dimiliki oleh masyarakat hukum adat berdasarkan musyawarah adat.

Setelah mengetahui jenis kepemilikan tanah pada masyarakat hukum adat Kampar, maka langkah selanjutnya ialah mengetahui status kepemilikannya. Status kepemilikan tanah pusako adalah hak milik yang dimiliki oleh individu yang bersifat privat, sedangkan status kepemilikan tanah wilayat dan tanah ulayat dilekatkan pada masyarakat hukum adat. Khusus tentang tanah ulayat telah diatur dalam Peraturan Daerah Kabupaten Kampar Nomor 12 Tahun 1999 tentang Hak Tanah Ulayat, yang mengatur tentang status kepemilikannya terdapat dalam Pasal 6 yang berbunyi, huruf (1) yaitu Hak Penguasaan Hak Tanah Ulayat dibuat atas nama Gelar Pemangku Adat yang berhak untuk itu sesuai dengan Ketentuan Hukum Adat setempat; huruf (2) yaitu Sertifikasi Hak Kepemilikan Tanah Ulayat diproses sesuai dengan ketentuan yang berlaku.

Status kepemilikan tanah soko khususnya masyarakat hukum adat Suku Bendang dari hasil wawancara bersama Dt. H. Ramli. R (Ketua Lembaga Adat Kampar) dan Datuk-datuk serta mamak yang berada di Desa Sawah Air Tiris, maka disimpulkan bahwa status kepemilikan tanah soko masyarakat hukum adat Suku Bendang adalah dilekatkan pada komunitas masyarakat yaitu pada suku tersebut yang memiliki garis keturunan ibu, hanya saja hak pakainya diserahkan kepada keturunan sebelah ibu atau anak perempuan.

Secara hukum adatnya, status tanah soko dilekatkan pada komunitas kesukuan, dalam komunitas kesukuan ada anak perempuan dan ada anak laki-laki, namun secara esensinya status tanah soko terlekatkan pada komunitas kesukuan pada keterunan perempuan atau ibu. Dapat dikatakan bahwa keturunan perempuan memegang status kepemilikan tanah soko, dan konsekuensi hukum adatnya adalah keturunan perempuan memperoleh hak pakai tanah soko. Walaupun status tanah soko baik kepemilikan komunal dan hak pakai, tetapi tanah soko tidak boleh diperjual-belikan kepada pihak lain dan manapun. Garis keturunan perempuan memang memiliki dan dapat menggunakan atau mengelola tanah (hak pakai), tetapi mereka bukanlah penentu kebijakan atas tanah tersebut. Ter Haar[9] mengatakan hak pakai itu adalah hak yang diberikan kepada seseorang untuk mengambil hasil dari sebidang tanah.

Posisi keturunan laki-laki pada masyarakat hukum adat Bendang adalah sebagai penentu kebijakan terkait permasalahan yang muncul terhadap tanah, karena yang menjadi Datuk yang dituakan oleh persukuan, dan yang menjadi mamak selaku pemberi nasehat kepada kemanakan adalah keturunan laki-laki. Keturunan laki-laki dibolehkan menggunakan atau memakai atau mengelola tanah soko. Tetapi ada syaratnya yaitu apabila keturunan perempuan tidak memakainya, namun status kepemilikan tetap terlekat pada keturunan perempuan.

Status kepemilikan berbeda dengan hak milik. Status kepemilikan bersifat komunal, dan akan beralih sesuai dengan ketentuan hukum adat. Sedangkan hak milik bersifat prifat, artinya penguasaan penuh terhadap objek yang menjadi hak milik tersebut. Penguasaan penuh itu berupa menguasai secara penuh apakah tanah hendak dijual, disewakan, dihibahkan, diwariskan, atau cara lainnya, diserahkan sesuai kehendak si pemegang hak milik.

\section{Peralihan Hak Kepemilikan dan Penyelesaian Sengketa Tanah Soko pada Masyarakat Adat Suku Bendang Kabupaten Kampar}

Pasca kemerdekaan Republik Indonesia, hukum yang berkaitan dengan tanah di awal-awal kemerdekaan masih menggunakan aturan pada masa jajahan, yang dilandaskan pada Pasal II Aturan Peralihan Undang-Undang Dasar 1945 yang berbunyi Segala badan negara dan peraturan yang ada 
masih langsung berlaku selama belum diadakan yang baru menurut Undang-Undang Dasar ini. Mengingat aturan yang mengatur tentang tanah yang menggunakan hukum barat belum sesuai dengan kondisi masyarakat Indonesia, maka tahun 1950 dibuatlah Undang-Undang Nomor 5 Tahun 1960 tentang Peraturan Dasar Pokok-Pokok Agraria (UUPA).

UUPA mengatur tentang peralihan kepemilikan tanah yaitu tanah yang berstatus hak milik, yang terdapat dalam Pasal 20 UUPA yang berbunyi hak milik adalah hal turun-menurun, terkuat dan terpenuh yang dapat dipunyai orang atas tanah. Hak milik yang dimiliki oleh orang dapat beralih dan dialihkan kepada pihak lain. Lebih lanjut dalam Pasal 26 UUPA menjelaskan peralihan kepemilikan atas tanah dapat dilakukan dengan cara Jual Beli; Penukaran; Penghibahan; Pemberian dengan Wasiat; Pemberian menurut adat, dan; Perbuatan-perbuatan lain yang dimaksudkan untuk memindahkan hak milik.

Peralihan kepemilikan tanah dalam UUPA juga dapat dilihat dalam Pasal 18 yang menyebutkan bahwa untuk kepentingan umum, termasuk kepentingan bangsa dan negara serta kepentingan bersama dari rakyat, hak-hak atas tanah dapat dicabut, dengan memberi ganti kerugian yang layak dan menurut cara yang diatur dengan undang-undang. Peralihan kepemilikan tanah yang semula dipegang atas dasar hak milik dapat beralih menjadi kepemilikan negara untuk kepentingan umum, kepentingan bersama, kepentingan bangsa dan negara.

Peralihan kepemilikan tanah terbagi menjadi 2 (dua) di antaranya adalah (a) peralihan kepemilikan tanah secara penuh, contohnya adalah jual beli tanah; (b) peralihan kepemilikan tanah tidak penuh, artinya adalah peralihan yang terjadi adalah berupa peralihan hak atas tanah, sehingga kepemilikan tanahnya masih dipegang secara hak milik, namun kepemilikan hak atas tanahnya diberikan kepada pihak ketiga, contohnya adalah Hak Guna Usaha (dalam Pasal 28-34 UUPA), Hak Guna Bangunan (dalam Pasal 35-40 UUPA), Hak Pakai (dalam Pasal 41-43 UUPA), Hak Sewa untuk Bangunan (dalam Pasal 44-45 UUPA), Hak Membuka Tanah dan Memungut Hasil Hutan (dalam Pasal 46 UUPA), serta Hak-Hak Tanah untuk Keperluan Suci dan Sosial (dalam Pasal 49 UUPA).

Soetomo menyebutkan secara yuridis terkait peralihan kepemilikan tanah dapat dilakukan melalui proses Jual beli; Hibah; Tukar menukar; Pemisahan dan pembagian biasa; Pemisahan dan pembagian harta waris; Penyerahan hibah dan wasiat; Hipotik; dan, Credit verband.[10] Iman Sudiyat dalam bukunya Hukum Adat menyebutkan bahwa dalam hukum tanah terkait dengan peralihan kepemilikan tanah atau peralihan hak atas tanah terbagi menjadi 3 (tiga) yaitu: (1) Menjual gadai, yaitu menyerahkan tanah untuk menerima pembayaran sejumlah uang secara tunai, dengan ketentuan si penjual tetap berhak atas pengembalian tanahnya dengan jalan menebusnya kembali, (2) Menjual lepas, yaitu menyerahkan tanah untuk menerima pembayaran sejumlah uang secara tunai, tanpa hak menebus kembal, jadi penyerahan itu berlaku untuk seterusnya dan selamanya, dan (3) Menjual tahunan, yaitu menyerahkan tanah untuk menerima pembayaran sejumlah uang secara tunai, dengan janji: tanpa suatu perbuatan hukum lagi, tanah itu akan kembali dengan sendirinya kepada pemiliknya, sesudah berlalu beberapa tahun atau beberapa kali panen (menurut perjanjian)[11].

Melihat berbagai macam bentuk peralihan kepemilikan tanah menurut UUPA dan pendapat para pakar, maka dapat disimpulkan menjadi: (1) Peralihan kepemilikan tanah atas jual beli, seperti jual beli tanah melalui perjanjian, dan jual beli tanah melalui proses pelelangan, (2) Peralihan kepemilikan tanah berjangka waktu atau peralihan hak atas tanah, seperti HGU, HGB, Hak Pakai, Hak Milik atas Satuan Rumah Susun, Jual Gadai, Jual Tahunan, dan lain-lainnya; (1) Peralihan 
kepemilikan tanah demi kepentingan umum, (2) Peralihan kepemilikan tanah atas waris, (3) Peralihan kepemilikan tanah atas hibah, (4) Peralihan kepemilikan tanah atas waqaf, (5) Peralihan kepemilikan tanah atas wasiat, dan (6) Peralihan kepemilikan tanah atas penukaran.

Perlu juga melihat peralihan kepemilikan tanah pada masyarakat hukum adat khususnya terkait tanah soko pada masyarakat hukum adat Suku Bendang. Tanah soko merupakan tanah turun temurun yang peralihan kepemilikannya berada pada garis keturunan perempuan (ibu). Datuk H. Ramli. R (Ketua Lembaga Adat Kampar) dalam wawancaranya beliau menyebutkan dahulu pada awalnya tanah soko itu hanya ada satu orang pemiliknya yaitu nenek moyang, kemudian nenek moyang membagi-bagikannya kepada keturunan perempuan, sehingga status kepemilikan tanah soko itu terletak pada anak kemenakan yang perempuan, kemudian dibagi untuk anak kemenakan yang perempuan secara turun temurun. Peralihan kepemilikan tanah soko pada masyarakat hukum adat kampar secara umum dan Suku Bendang pada khususnya, yang dilakukan dengan turun temurun pada garis keturunan ibu.

Pada prakteknya pernah terjadi sebuah kasus peralihan kepemilikan tanah soko Suku Bendang di Desa Sawah Air Tiris Kabupaten Kampar yang mana terjadi perebutan tanah soko antara anak kemenakan perempuan. Ada sebidang tanah yang selama ini telah diturunkan oleh anak kemenakan perempuan dari keluarga pertama, dan datuk-datuk Suku Bendang yang ada di Desa Sawah juga mengatakan hal demikian. Namun anak kemenakan perempuan yang lainnya mengatakan bahwa ibunya pernah berwasiat bahwa sebidang tanah tersebut adalah tanah soko mereka, dan itu tanpa ada saksi yang mendengar ketika ibunya berwasiat.

Agar kasus tanah soko ini tidak berlarut-larut dan menimbulkan perpecahan antara sesama anak kemenakan pada Suku Bendang maka diselesaikan secara internal sesama Suku Bendang, maka ada upaya penyelesaiannya, yaitu dengan menghadirkan Datuk-Datuk yang dituakan di Suku Bendang, Mamak-Mamak Suku Bendang, Para Pihak yang berselisih, Tokoh Agama, dan Tokoh Masyarakat. Musyawarah adat ini dilakukan dengan seksama, semua saksi-saksi dan bukti-bukti dipaparkan di hadapan musyawarah adat tersebut. Kedua belah pihak yang berselisih paham samasama saling membenarkan argumennya masing-masing.

Sampailah pada satu titik kesimpulan yang diambil jalan tengahnya yaitu tanah soko tersebut dibagi menjadi 2 (dua) yaitu setengah bidangnya untuk kemanakan perempuan pertama, dan setengah bidang tanah soko yang berikutnya untuk kemanakan perempuan yang lainnya. Pengambilan keputusan untuk mengalihkan kepemilikan tanah soko dilakukan dengan musyawarah adat yang membagi tanah soko tersebut. Pada akhirnya para pihak yang berselisih saling menyampaikan permohonan maaf. Setelah dilaksanakannya musyawarah adat maka kondisi ikatan kesukuan kembali seperti semula.

Kasus ini menjadi kasus pertama yang pernah ada dalam penyelesaian permasalahan tanah khususnya tanah soko. Dari kasus tersebut dapat diambil manfaat keilmuan bahwa macam-macam bentuk peralihan kepemilikan tanah menjadi bertambah yaitu peralihan kepemilikan tanah atas penyelesaian sengketa adat yang kedua belah pihak sama-sama mendapatkan tanah soko tersebut.

Kasus tersebut secara esensi diselesaikan dengan berlandaskan pada konsep Alquran dan Sunnah. Para pihak lebih mengutamakan nilai-nilai kekeluargaan, tidak bertikai, dan membagi dengan cara yang adil. Islam juga mengajarkan keadilan dalam setiap urusan manusia, seperti yang termaktub dalam Firman Allah SWT pada Q.S. An-Nisaa' Ayat 58 yaitu "Sesungguhnya Allah menyuruhmu menyampaikan amanat kepada yang berhak menerimanya, dan (menyuruh kamu) apabila menetapkan hukum di antara manusia supaya kamu menetapkan dengan adil". Islam juga 
memerintahkan agar setiap manusia menjadi penegak hukum yang adil, tentunya dalam penyelesaian ini peran Datuk dan Ninik Mamak sebagai penimbang mana yang benar dan mana yang salah, harus memiliki sikap adil, seperti yang termaktub di dalam Alquran Surat An-Nisaa' Ayat 135 yang berbunyi "Wahai orang-orang yang beriman, jadilah kamu orang yang benar-benar penegak keadilan, menjadi saksi karena Allah walaupun terhadap dirimu sendiri atau ibu, bapak dan kaum kerabatmu”.

Peralihan kepemilikan tanah soko pada masyarakat adat Suku Bendang dengan cara jual beli tidak dibenarkan karena sifat utama tanah soko adalah bersifat turun temurun, sehingga tidak boleh diperjual-belikan. Datuk. H. Ramli. R (Ketua Lembaga Adat Kampar) menyebut bahwa apabila tanah soko diperjual belikan maka perilaku demikian adalah penyimpangan. Lebih lanjut dikatakan bahwa dalam kondisi-kondisi tertentu, tanah soko dapat dijual dengan syarat: (1) Anak kemenakan perempuan sebagai pemegang kepemilikan tanah soko sedang mengalami sakit parah yang sembuhnya lama sekali, artinya tidak ada yang mengobati, dan tidak punya biaya sama sekali, serta tidak punya pilihan lain, maka tanah soko dapat dijual, (2) Anak kemenakan perempuan sebagai pemegang kepemilikan tanah soko sudah tua dan lambat meninggalnya, tidak ada yang merawatnya, dan membutuhkan kebutuhan sehari-hari untuk hidup, maka tanah soko tersebut dapat dijual, dan (3)Apabila Anak kemenakan perempuan sebagai pemegang kepemilikan tanah soko telah terbujur di atas atau di dalam rumah, artinya tidak memiliki biaya untuk menyelenggarakan mayatnya, maka tanah soko tersebut dapat dijual.

Melihat uraian di atas tentang peralihan kepemilikan tanah soko pada masyarakat adat Suku Bendang, maka dapat disimpulkan bahwa macam-macam bentuk peralihan kepemilikan tanah soko, yaitu: (1) Peralihan kepemilikan tanah antar generasi menurut garis keturunan. Terkait dengan peralihan kepemilikan tanah soko pada masyarakat hukum adat Suku Bendang dilakukan turuntemurun berdasarkan garis keturunan perempuan, (2) Peralihan kepemilikan tanah atas penyelesaian sengketa tanah. Khususnya pada kasus sengketa tanah soko yang diselesaikan dengan musyawarah adat, dan kemudian diputuskan bahwa tanah soko dibagi menjadi dua.

\section{Kesimpulan}

Berdasarkan uraian pada pembahasan di atas, maka dapat ditarik kesimpulan, yaitu: Pertama, Status kepemilikan tanah soko pada masyarakat adat suku bendang kabupaten kampar adalah dilekatkan pada komunitas masyarakat yaitu pada suku tersebut yang memiliki garis keturunan ibu, dan hak pakainya juga diserahkan kepada keturunan sebelah ibu atau anak perempuan. Garis keturunan perempuan memang memiliki dan dapat menggunakan atau mengelola tanah (hak pakai), tetapi mereka bukanlah penentu kebijakan atas tanah tersebut. Posisi keturunan laki-laki pada masyarakat hukum adat Bendang adalah sebagai penentu kebijakan terkait permasalahan yang muncul terhadap tanah, karena yang menjadi Datuk yang dituakan oleh persukuan, dan yang menjadi mamak selaku pemberi nasehat kepada kemanakan adalah keturunan laki-laki. Kedua, Peralihan kepemilikan tanah soko pada masyarakat adat suku bendang kabupaten kampar adalah terbagi menjadi 2 (dua) yaitu (a) Peralihan kepemilikan tanah antar generasi menurut garis keturunan. Terkait dengan peralihan kepemilikan tanah soko pada masyarakat hukum adat Suku Bendang dilakukan turun-temurun berdasarkan garis keturunan perempuan; dan (b) Peralihan kepemilikan tanah atas penyelesaian sengketa tanah. Khususnya pada kasus sengketa tanah soko yang diselesaikan dengan musyawarah adat, dan kemudian diputuskan bahwa tanah soko dibagi menjadi dua. Penyelesaian sengketa tanah soko pada masyarakat adat suku bendang kabupaten 
kampar adalah dengan mengedepankan cara-cara penyelesaian melalui musyawarah, kekeluargaan dan keadilan. Hal ini juga sejalan dengan perintah dari Alquran dan Sunnah, sesuai dengan konsep utama masyarakat hukum adat Kampar yang mengedepankan 'adat bersandi syara', dan syara" bersandi kitabullah".

\section{Daftar Pustaka}

[1] “IPI UNIFIKASI DALAM PLURALISME HUKUM TANAH DI INDONESIA (REKONSTRUKSI KONSEP UNIFIKASI DALAM UUPA) : View Article." [Online]. Available: http://id.portalgaruda.org/?ref=browse\&mod=viewarticle\&article=12548. [Accessed: 20-Dec-2018].

[2] A. R. Erman, "KERUKUNAN DAN KEARIFAN LOKAL DALAM HAK-HAK MASYARAKAT HUKUM ADAT KAMPAR," TOLERANSI, vol. 4, no. 2, pp. 206-228, Dec. 2012.

[3] B. Sunggono, Metodologi penelitian hukum. 2007.

[4] "IPI POLITIK HUKUM DALAM PEMBERIAN KEWENANGAN BIDANG PERTANAHAN KEPADA PEMERINTAHAN DAERAH : View Article." [Online]. Available: http://id.portalgaruda.org/?ref=browse \&mod=viewarticle\&article=10308. [Accessed: 20-Dec-2018].

[5] "IMPLIKASI PUTUSAN MAHKAMAH KONSTITUSI MENGENAI STATUS HUTAN ADAT SEBAGAI HUTAN HAK | Cahyaningrum | Kajian." [Online]. Available: http://jurnal.dpr.go.id/index.php/kajian/article/view/566. [Accessed: 20-Dec-2018].

[6] A. Luthfi, Hukum dan Perubahan Struktur Kekuasaan, Pelaksanaan Hukum Islam dalam Kesultanan Melayu Siak 1901-1942. Pekanbaru: Susqa Press, 1991.

[7] R. Bey, Sejarah Perjuangan Daerah Kampar dengan Segala Aspeknya, Serta Kumpulan Data Kerajaan di Indonesia. Bangkinang: SMTP-SMU, 2000.

[8] R. Y. Zakaria, "Strategi Pengakuan dan Perlindungan Hak-Hak Masyarakat (Hukum) Adat: Sebuah Pendekatan Sosio-Antropologis," BHUMI: Jurnal Agraria dan Pertanahan, vol. 2, no. 2, pp. 133-150, Sep. 2018.

[9] T. Haar, Asas-Asas dan Susunan Hukum Adat. Jakarta: Pradnya Paramita, 1981.

[10] E. Indriasari, "Tinjauan Yuridis Peningkatan Jual Beli Tanah dan Bangunan Menurut Kitab Undang-Undang Hukum Perdata," Tegal, 2015.

[11] I. Sudiyat, Hukum Adat, Sketsa Asas. Yogyakarta: Liberty, 2007. 
Fikri: Jurnal Kajian Agama, Sosial dan Budaya

Hengki Firmanda 